\title{
Mucosa-Associated Lymphoid Tissue Lymphoma Translocation Protein 1
}

National Cancer Institute

\section{Source}

National Cancer Institute. Mucosa-Associated Lymphoid Tissue Lymphoma

Translocation Protein 1. NCI Thesaurus. Code C60673.

Mucosa-associated lymphoid tissue lymphoma translocation protein 1 (824 aa, $\sim 92 \mathrm{kDa}$ )

is encoded by the MALT 1 gene. This protein may play a role in NF-kappa-B activation. 